International Journal of Education (IJE), Vol. 3, No. 3, September 2015

\title{
PREDICTORS OF TEACHER COLLABORATION AND ON THE JOB EFFECTIVENESS
}

\author{
Dr. Ozoh, Michael. C. And Dr. A. A. Ladan \\ Department Of Educational Psychology, \\ Federal University Of Education Zaria.
}

\begin{abstract}
:
The study investigated the predictors of collaborative behavior and on the job effectiveness among teachers. The population of the study involve teachers within Zaria metropolis. Hence, two hundred of them were purposively sampled for the purpose of the study. Three research questions were formulated to guide the study. The questionnaire was structured in a five point Liker scale system. Any item that achieve mean score of 3 point and above was taken to be accepted, while those that did not achieve that was taken as rejected. All the items on interaction, relationship and motivation were found to be accepted by the respondents as critical variables for facilitating teachers' collaboration and on the job effectiveness. It was found that constant interaction among teachers enhances collaboration and effectiveness. The study also revealed that the more teachers relate with one another, the more close they are and also influence each other's effectiveness. The study further showed that teachers motivation, influences effectiveness. It was therefore recommended that teachers themselves should establish mechanisms that would help them interact and relate more efficiently with one another on constant bases.
\end{abstract}

\section{Keywords:}

Predictor, teacher Collaboration, On the Job Effectiveness.

\section{Introduction:}

Teacher interaction affects teacher performance in several ways which in essence enhance on the job effectiveness. It involves the process of seating together and brain storming on their work as well as assessing ways of enhancing their professional practice. Interaction is what enhances teaching learning process and proactive approach to professional practice. Teacher interaction is a relational process that brings teachers together to discuss their ideal professional engagements or realistic professional practice as a way or means of enhancing their effectiveness in the practice. It encompasses the procedure through which conversation transforms individualistic approach to a more advanced approach through supportive process. The interaction process necessitates continuous exchange of professional experience as well as effective integration into the main stream of teaching practice. Wilson and Berne (1999), McLaughlin and Talbert (2001) found teacher conversation and collaboration to be important component of professional development. Horn (2006) sees teacher conversation as a forum through which abstract pedagogical ideals are translated into complex realities. Nnachi (2009) points out the significance of group influence on learning process. To him, for effective learning to occur, "the group one belongs to makes 
significant contribution". People always share significant influence of others which in essence contributes to their behavior models or change in individual approach. This constitutes immensely to the process that gives teachers the opportunity to involve themselves into collective assessment strategies and team work. Horn further asserted that teachers consider disclosure and discussion of the problems emanating from professional practice an important purpose for coming together.

Their focus on other important professional issues makes their interaction process very mandatory for the purpose of achieving effectiveness. Teacher interactive session serves as an effective tool for fast tracking collaborative activities among themselves which gives credence to productive activities with the intention of proactive approach being introduced into their work order or ethics. The effectiveness of establishing interactive communities among teachers can be fast tracked or effectively enhanced only when there is a progressive interactive session maintained by teachers. This is where their experiences, new ideas and activities are exchanged for the benefit of others in order to enhance their productivity or teaching and learning outcomes.

\section{Literature Review:}

\section{Teacher's Social Interaction as a Predictor for teacher collaboration and professional effectiveness.}

Onyekwere, (2013) looked at collaboration and its effect on job efficiency and asserted that organizations rely on teamwork for their success, efficient inter- professional collaborative effort becomes a crucial tool for achieving organizational goals. Orebiyi and Orebiyi (2011), observes that interpersonal interactions involving the exchange of information between employees, peers and top management staff can have significant effects on the employees' psychological job output such as job satisfaction, organizational commitment, burnout and turnover intentions. They further stated that interactions enable teachers gain insight and knowledge about the background, experiences, attitudes and behaviours of others. To them, when the interaction establishes friendship process, it affects the growth of the schools and the teachers positively. It is evident therefore that teachers personal development on the job and the ability to maintain professional effectiveness depends on the interaction process established within the work order. This shows that the days of isolative work order is over if the teacher should develop a productive work behavior. Horn (2006) reported teacher conversation as a factor that sustains professional engagement in such a way that high quality professional development is maximized. When there is effective interaction among teachers, it extends to establishing effective relationship with students, their families, parents, the school and the society at large. It can lead to sustained problem solving process in the profession. Raganee (2008) asserted that teacher participation in whole school or team collaboration inquiry and problem solving remains a norm. When teachers learn collaboratively, it also implies learning to improve individual professional practice which eventually translates into wide consultative process as well as more effective student's learning process. The interaction process in the professional engagement widens the opportunities for active participation of professionals in identification of individual needs and professional needs, complementary planning, implementation, and evaluation process involved in the practice. This is evidenced in shared identification, shared professional development needs, working together in planning, implementation and evaluation of school initiatives, sharing research findings to guide and enhance practice, as well as engaging in professional conversation about teaching and 
International Journal of Education (IJE), Vol. 3, No. 3, September 2015

learning. It has been observed that interaction among teachers can to a large extent stimulate social facilitation and help to maintain closer relationship (Magnus. 2009). He further opined that where interaction process is weak, it can also weaken productivity trust, respect and commitment.

Little (1990) asserts that teacher's collaborative effort is a way of "talking about teaching" which includes planning, sharing, preparation, classroom observation, corporative training and individual training. By this practice teachers efficiently enrich themselves through rich experiences and knowledge of their colleagues acquired theoretically and practical based meaningful ideas through exchange programmes (Wallace, 2006). He further notes that the establishment of discussion

communities among teachers is very important, hence it assist teachers to develop or acquire new roles and changing ideas. Van Driel, Beijaard, and Verloop (2001) assert that teacher learning network provides effective means of communication among peers. To them this has the potential to reduce resistance to change and innovation. In the same vein, Wallace (2006) study revealed several issues that boarder on teacher collaboration and communication. In the first instance, teacher collaborative activities provide cognitive and effective support for teachers. Communication also provides opportunity for teachers to share their similarities and experiences which give better understanding of classroom practice. Teachers benefit from resources, divers thinking process, increased reflection on their activities. It provides more eclectic approach for classroom instruction as well as more confidence in their professional practice.

\section{Teacher's Relationship}

Relationship among teachers is a strong unifying factor when it comes to work proficiency, on the job effectiveness and professional efficiency. According to Inger (1993) some schools encourage collegial relationships among teachers which in essence produce immense benefits for students, teachers and the school. In essence, Oribiyi and Oribiyi (2011) observed that teacher's relationship cooperation with colleagues would help to facilitate their success at work. These relationships are summed up in a collaborative forum. When teaches collaborate, it facilitates the reduction of the complexity of tasks being undertaken by individual teachers. New ideas and thoughts of better ways of performing their professional tasks are acquired. In some cases they are better empowered and equipped for effectiveness in the work experiences. It is obvious that teaching as a very stressful task with it's over bearing effect is often expressed on the individual teachers. But collaborative effort based on mutual relationship reduces this stress effect hence such situations are shared among the members of the team.

The study of Kizza (2009), on employee relationships as correlates job performance among secondary school teachers revealed that there is a significant positive correlation between teachers' relationship with one another and their job performance. He further explained that Teacher-to-

teacher relationships are the interrelationships between a teacher and fellow teachers. According to

Inger (1993:1) "Teacher collaboration in urban schools breaks the isolation of the classroom, lead to increased feeling of effectiveness and satisfaction". Hence researchers' view is that collaboration should be carried out on equal relationship among members of the collaborative 
team. It should be based on the premise of sharing knowledge and experiences from all parties involved (Ferrara,

2000). Starr (2010:4) comments that "This process encourages risk taking and adds to knowledge that directly benefits the collaborative process". The immense advantages teachers derive from such a relationship to a large extent transforms their dormant individual professional expertise into more contemporary experiences. Such processes as shared planning, assessment responsibility, understanding of individual student's needs, clarification of learning outcomes and experiences among others are derivatives of such engagements. King (2006) reported that the active role teachers' play in initiating change is due to collaborative relationship among them.

Anderson and Ward (2005) enumerated the benefit one gets in a collaborative relationship as the ability to provide more direct instructional activities and differentiated content planning, preparation, reduced student teacher ratio, professional learning opportunities, less disciplinary cases for referrals. To them, this eventually leads to overall sense of support. According to Gable and Manning (2009), professional collaboration affect education practice and approaches as teachers share planning, goal settings, collective decision making and implementation of programme for effectiveness. Audu and Oliha (2008) asserted that teacher morale can serve as an essential factor in the successful implementation of educational programmes.

Moore (2005) opines that Teaching is one of the most stressful jobs .To justify this, a survey that assess levels of stress as it affects various jobs by health and safety executive shows that teaching came top. Subsequently, it is agreed that teaching workload is excessive. This is evidenced in the sense that actual working hours may be shorter, but at home, teachers spend most of their time preparing lessons, lesson pan, marking assignments, tests or examinations. Furthermore, an analysis of calls to "Teacher Support Line" show that the most concern shown by teachers always is stress and 27\% of them are found to fall within this category" (Moore, 2005:2). But with a relational process that provides opportunity for shared responsibility, the burden of the stress is grossly and drastically reduced. New Teacher Center (NTC) (2007) comments that children taught by effective teachers are found to perform better than those taught by ineffective teachers. Onete, Udey, Ogbor (2011) asserted that Nigerian teachers are passing through great deal of stress experience.

Armstrong (2009) reported that $87 \%$ percent of teachers suffered stress in last two years, while $42 \%$ suffered depression, $60 \%$ of the problems emanated from issues in the workplace, $82 \%$ had sleeping problems and 53\% lack concentration. He further notes that the scale and significance of health and wellbeing problems in the teaching profession are clear. Problems are prevalence and they are having costly impact on students, colleagues, and the individuals concerned. A number of participants argued that teaching like other professions was inevitably stressful. Nevertheless, all agreed that urgent attention is needed to be given to the way in which schools and government treat the causes and occurrences of stress. It was pointed out that some of the best schemes for minimizing stress were in the private sector where employers are open about the possibility of stress and actively provide and promote support for it. Of vital importance to the success of such support were the early identification of stress and other common health problems enabling people to act quickly and prevent the rapid determination that can follow.

Teacher Support Network (2005) reported that $80 \%$ of respondents have suffered from work related stress including panic attacks, work load and bulling at work. In essence, teacher's 
International Journal of Education (IJE), Vol. 3, No. 3, September 2015

motivation could have tremendous effect on their work performance and effectiveness. Nwachukwu (2011) opines that motivation is necessary or learning that strategies should be evolved to organize a continuous interactive motivational dynamics for maximum effectiveness. According to Bartell (1990) an effective educational environment has the capacity to provide positive school climate where teachers and students feel comfortable about learning educational process and hence foster caring attitude. The level of effectiveness of teachers to a large extent could be determined by the motivational responses available to them. Hence, Audu and Oliha (2008) also note that once there is high morale among teachers it will also affect students. Hence, in essence motivation plays vital role in enhancing teacher effectiveness. Whatever happens to teacher, also affects students learning outcomes. Once teachers are motivated, they are bound to seek for the means of sustaining the longevity of their professional practice, effectiveness, and higher productivity.

\section{Teacher Motivation and Theatrical Bases}

The fundamental way of sustaining teachers' effectiveness in educational system is through motivational process. Commitment to work remains a function of motivation. Motivational process allows for increase in input and output. In line with the thought of Audu and Oliha (2008) that high morale helps to create a more conducive, inviting and stable environment. It has been noted that motivation has the capacity of compensating for the difficulties and challenges experienced in the profession by teachers (Okoro, 2008). In accordance with Burton (2012), the more motivated an employee is, the more likely they are to have organizational commitment and identify themselves with the organization and this will meet some of the unmet needs, and connect them with the organization.

Motivation of teachers seems to be more necessary now due to the pressure on the profession by challenges of contemporary development and technological advancement. Loss of interest and enthusiasm in the profession can be compensated through motivational ideals (Okoro, 2008). In agreement with Adams equity theory of motivation of 1963 which emphasis the need to motivate the employee in order to achieve greater output. The theory stated that fair treatment of the people remains a factor of motivation, in the other way round, when they feel unjustly or unfairly treated, the give in to feelings of disaffection and demotivation. Teachers' comparison of their income which they considered very critical to their motivation is in consonance with the equity theory which stated that people make comparison with their reward and the reward of others who are in a similar situation. Hence, he called for fairness in the reward system between input and output of the employee. This as well applies to teachers considering the fact that they hold the key to the development of the society. .Abraham Maslow's theory of human need emphasized the need for the satisfaction of basic needs as one climbs the ladder. The motivation of teachers will serve the school and students well, because it based on their motivation that their commitment to teaching becomes more effective and hence transcends into positive effect on students learning as well as positive outcomes. The conception towards teachers willful engagement to effective work order is based on their motivation by relevant authorities. According to Akpan (2013), the believe is that once once teachers' pay, working conditions and fringe benefits given to teachers are judged to be good by the teachers, they will put in more effort at work.

Teachers can motivate each other through constant interaction. This serves as a forum where issues concerning the profession can be discussed, and performance evaluation carried out. By this action, individual challenges can be given a unified attention or approach and will eventually 
International Journal of Education (IJE), Vol. 3, No. 3, September 2015

be eliminated. This is necessary due to the important place the teacher occupies in the developmental process of a nation. Gbenga (2010), opines that the teacher is the most important of all the resources needed to actualize goals of achieving a viable economy. Hence motivating them translates into creating a viable and stable economy. Akpan (2013) asserts that the success or failure of any educational system depends mainly on the teachers. This is where effective motivation of teachers' comes to play. It is a well-known fact that a well-motivated teacher, who is provided with working incentives, good working conditions and adequate remuneration is bound to be dedicated to his/ her teaching so as to bring about the needed learning on the part of students.

\section{Statement of the problem:}

It is well known fact that teachers work order is based on individualistic tendencies. This has formed the opium of teaching profession over time. Teachers scarcely come together to share their work ethics, professional practices, plan together, as well as design implementation framework. The research tends to initiate a process of collaboration that will facilitate this process.

\section{Research questions:}

1. What is the relationship between teacher interaction and professional effectiveness?

2. Does teachers' relationship have any impact on their collaboration and effectiveness in practice?

3. What is impact of motivation on teachers' collaboration and effectiveness?

\section{Methodology:}

The research design used for the study was a survey. The population comprised of teachers in Zaria. A sample of 200 was randomly selected, out of which 155 of them responded and returned their questionnaire. The design is suitable for this study since the incidence of the study is an observable fact which deals with teachers on the job experiences and professional practice.

\section{Instrumentation:}

The main instrument used for collecting data was a well-structuredquestionnaire. The instrument which was designed by the researcher was validated by senior lectures in the department of Educational Psychology Federal College of Education Zaria and others from Ahmadu Bello University Zaria.

\subsection{Results:}

\subsubsection{Research question one:}

What is the relationship between teacher interaction and professional effectiveness? 
International Journal of Education (IJE), Vol. 3, No. 3, September 2015

Table 1. Mean and Standard Deviation of Respondents on the Impact of interaction on Teacher Collaboration and Effectiveness.

\begin{tabular}{|c|c|c|c|c|c|c|c|c|c|}
\hline \multirow[t]{2}{*}{$\mathbf{S} / \mathbf{N}$} & \multirow[t]{2}{*}{ Social Interaction } & \multicolumn{5}{|c|}{ Response Categories } & \multirow[b]{2}{*}{$\begin{array}{l}\text { Me } \\
\text { an }\end{array}$} & \multirow[b]{2}{*}{$\begin{array}{l}\text { S. } \\
\text { D }\end{array}$} & \multirow[b]{2}{*}{$\begin{array}{l}\text { DE } \\
\mathbf{C}\end{array}$} \\
\hline & & SA & $\mathbf{A}$ & $\begin{array}{l}\text { UN } \\
\text { D }\end{array}$ & DA & $\begin{array}{l}\text { S } \\
\mathbf{D} \\
\mathbf{A}\end{array}$ & & & \\
\hline 1. & $\begin{array}{l}\text { By constant interaction with each other, } \\
\text { improvement on competence is facilitated }\end{array}$ & $\begin{array}{l}87 \\
(56.1 \\
\%) \\
\end{array}$ & $\begin{array}{l}67 \\
(43 . \\
2 \%) \\
\end{array}$ & & $\begin{array}{l}1 \\
(.6 \\
\%) \\
\end{array}$ & - & 4.55 & .51 & A \\
\hline 2. & $\begin{array}{l}\text { Discussion of weak areas with other teachers } \\
\text { helps to improve potentials }\end{array}$ & $\begin{array}{l}73 \\
(47.3 \\
\%)\end{array}$ & $\begin{array}{l}76 \\
(49 . \\
0 \%)\end{array}$ & $\begin{array}{l}4 \\
(2.6 \\
\%)\end{array}$ & $\begin{array}{l}2 \\
(1 . \\
3 \% \\
)\end{array}$ & - & 4.42 & .61 & A \\
\hline 4. & $\begin{array}{l}\text { There is always exchange of ideas when } \\
\text { teachers discusses with one another }\end{array}$ & $\begin{array}{l}97 \\
(62.6 \\
\%)\end{array}$ & $\begin{array}{l}48 \\
(31 . \\
0 \%)\end{array}$ & $\begin{array}{l}6 \\
(3.9 \\
\%)\end{array}$ & $\begin{array}{l}2 \\
(1 . \\
3 \%\end{array}$ & $\begin{array}{l}2 \\
(1 \\
.3\end{array}$ & 4.52 & .75 & A \\
\hline 5. & $\begin{array}{l}\text { There is exchange of ideas when teachers } \\
\text { discuss with each other. }\end{array}$ & $\begin{array}{l}88 \\
(56.8 \\
\%)\end{array}$ & $\begin{array}{l}50 \\
(32 . \\
3 \%)\end{array}$ & $\begin{array}{l}11 \\
(7.1 \\
\%)\end{array}$ & $\begin{array}{l}4 \\
(2 . \\
6 \%\end{array}$ & $\begin{array}{l}2 \\
(1 \\
.3\end{array}$ & 4.40 & .83 & A \\
\hline 6. & $\begin{array}{l}\text { Teachers interaction with one another } \\
\text { facilitates high degree of professional inputs }\end{array}$ & $\begin{array}{l}59 \\
(38.1 \\
\%)\end{array}$ & $\begin{array}{l}75 \\
(48 . \\
4 \%) \\
\end{array}$ & $\begin{array}{l}13 \\
8.4 \\
\%) \\
\end{array}$ & $\begin{array}{l}6 \\
(3 . \\
9 \% \\
\end{array}$ & $\begin{array}{l}2 \\
(1 \\
.3\end{array}$ & 4.18 & .84 & A \\
\hline 7. & $\begin{array}{l}\text { Interaction among teachers enhances } \\
\text { individual development }\end{array}$ & $\begin{array}{l}51 \\
(32.9 \\
\%)\end{array}$ & $\begin{array}{l}83 \\
(53 . \\
5 \%)\end{array}$ & $\begin{array}{l}9 \\
5.8 \\
\%)\end{array}$ & $\begin{array}{l}6 \\
(3 . \\
9 \%\end{array}$ & $\begin{array}{l}6 \\
(3 \\
.9\end{array}$ & 4.08 & .94 & A \\
\hline
\end{tabular}

In table 1 above, most of the responses of respondents to the items had mean of 4 and above, showing that all items of interaction among teachers achieve its objectives of facilitating collaboration and effectiveness on the job among professional teachers. In all, $56.1 \%$ of teachers strongly agree that constant interaction among teachers enhances individual development. While $62.6 \%$ strongly agree that exchange of ideas among teacher also contributes effectively to professional effectiveness.

\subsubsection{Research questions two:}

Does teacher relationship have any impact on professional effectiveness?

Table 2. Mean and Standard Deviation on the Impact of Relationship among teachers on Collaboration and Effectiveness.

\begin{tabular}{|l|l|l|l|l|l|l|l|l|l|}
\hline & Relationship & SA & A & UND & DA & $\begin{array}{l}\text { SD } \\
\text { A }\end{array}$ & $\begin{array}{l}\text { M } \\
\text { EA } \\
\text { N }\end{array}$ & $\begin{array}{l}\text { SD } \\
\text { DE } \\
\text { C }\end{array}$ \\
\hline 1. & Cooperation among & $69(44.5$ & $72(46$. & $14(9.8$ & - & - & 4.3 & 64.2 & A \\
\hline
\end{tabular}


International Journal of Education (IJE), Vol. 3, No. 3, September 2015

\begin{tabular}{|l|l|l|l|l|l|l|l|l|l|}
\hline & $\begin{array}{l}\text { teachers improve } \\
\text { profession } \\
\text { effectiveness }\end{array}$ & $\%)$ & $5 \%)$ & $\%)$ & & & 6 & 1 & \\
\hline 2. & $\begin{array}{l}\text { Good working } \\
\text { relationship } \\
\text { facilitates } \\
\text { individual } \\
\text { effectiveness }\end{array}$ & $\begin{array}{l}71(45.8 \\
\%)\end{array}$ & $\begin{array}{l}68(43 . \\
9)\end{array}$ & $\begin{array}{l}6(3.9 \\
\%)\end{array}$ & $\begin{array}{l}8(5 . \\
2 \%\end{array}$ & $\begin{array}{l}2(1 \\
.3 \\
\%\end{array}$ & $\begin{array}{l}4.2 \\
8\end{array}$ & $\begin{array}{l}86.4 \\
4\end{array}$ & $\mathrm{~A}$ \\
\hline 3. & $\begin{array}{l}\text { When teachers are } \\
\text { closely related it } \\
\text { increase the pride } \\
\text { of profession }\end{array}$ & $50(32.3$ & $66(42$. & $13(8.4$ & $20(1$ & $6(3$ & 3.8 & 012 & $\mathrm{~A}$ \\
$\%$ & $6 \%)$ & 2.3 & .9 & 6 & 283 & \\
\hline 4. & $\begin{array}{l}\text { Cordial } \\
\text { relationship among } \\
\text { teachers }\end{array}$ & $69(44.5$ & $\begin{array}{l}63(40 . \\
6 \%)\end{array}$ & $\begin{array}{l}19(12 . \\
3 \%)\end{array}$ & $\begin{array}{l}4(2 . \\
6 \%\end{array}$ & - & $\begin{array}{l}4.2 \\
7\end{array}$ & $\begin{array}{l}77.5 \\
5\end{array}$ & $\mathrm{~A}$ \\
\hline 5. & $\begin{array}{l}\text { Good relationship } \\
\text { facilitate effective } \\
\text { interaction among } \\
\text { teachers }\end{array}$ & $\begin{array}{l}71(45.8 \\
\%)\end{array}$ & $\begin{array}{l}67(43 . \\
2 \%)\end{array}$ & $\begin{array}{l}13(8.4 \\
\%)\end{array}$ & $\begin{array}{l}4(2 . \\
6 \%\end{array}$ & - & $\begin{array}{l}4.3 \\
2\end{array}$ & $\begin{array}{l}73.7 \\
9\end{array}$ & $\mathrm{~A}$ \\
\hline
\end{tabular}

Table 2 shows that most responses to the items also had mean of 4 and above, hence indicating that when there is good relationship among teachers, collaboration and on the job effectiveness receive more boast. The study shows that $44.5 \%$ strongly agree and $46.5 \%$ agree that cooperation among teachers improves on the job effectiveness. Also $45.8 \%$ strongly agree as well as $43.9 \%$ agree that good relationship facilitates individual effectiveness. In the same vein, $45.8 \%$ strongly agree, $43.2 \%$ also agree that good relationship among teachers facilitate effective interaction which in turn affects collaboration and on the job effectiveness.

\subsubsection{Research questions three:}

What is the impact of motivation on professional effectiveness?

Table 3. Mean and Standard Deviation of Respondent's on the impact of motivation on Teachers' Collaboration and Effectiveness.

\begin{tabular}{|l|l|l|l|l|l|l|l|l|l|}
\hline $\begin{array}{l}\text { S/ } \\
\text { N }\end{array}$ & Motivation & SA & A & UND & DA & $\begin{array}{l}\text { SD } \\
\text { A }\end{array}$ & $\begin{array}{l}\text { Me } \\
\text { an }\end{array}$ & $\begin{array}{l}\text { S } \\
\text { D }\end{array}$ & $\begin{array}{l}\text { D } \\
\text { E } \\
\text { C }\end{array}$ \\
\hline 1. & $\begin{array}{l}\text { We make more progress } \\
\text { when we are closely related. }\end{array}$ & $\begin{array}{l}57 \\
(36 \\
.8\end{array}$ & $\begin{array}{l}74 \\
(47 \\
\%)\end{array}$ & $\left.\begin{array}{l}19 \\
(12 .\end{array}\right)$ & $\begin{array}{l}5 \%) \\
(3.2\end{array}$ & $\begin{array}{l}\%) \\
\%)\end{array}$ & $\begin{array}{l}4.1 \\
8\end{array}$ & $\begin{array}{l}76 \\
.8\end{array}$ & A \\
5 & \\
\hline 2. & $\begin{array}{l}\text { Performance of others spurs } \\
\text { me into action in the work }\end{array}$ & $\begin{array}{l}44 \\
(28\end{array}$ & $\begin{array}{l}93 \\
(60\end{array}$ & $\begin{array}{l}13 \\
(8.4)\end{array}$ & 2 & $\begin{array}{l}3 \\
(1 .\end{array}$ & $\begin{array}{l}4.1 \\
2\end{array}$ & $\begin{array}{l}76 \\
.0\end{array}$ & A \\
\hline
\end{tabular}


International Journal of Education (IJE), Vol. 3, No. 3, September 2015

\begin{tabular}{|c|c|c|c|c|c|c|c|c|c|}
\hline & place & $\begin{array}{l}.04 \\
)^{2}\end{array}$ & $\begin{array}{l}.0 \\
\%)\end{array}$ & & $\begin{array}{l}(1.3 \\
\%\end{array}$ & $\begin{array}{l}9 \% \\
)\end{array}$ & & 4 & \\
\hline 3. & $\begin{array}{l}\text { I am challenged by the } \\
\text { progress of others }\end{array}$ & $\begin{array}{l}56 \\
36 . \\
1\end{array}$ & $\begin{array}{l}83 \\
(53 \\
.5 \\
\%\end{array}$ & $\begin{array}{l}10 \\
(6.5 \\
\%)\end{array}$ & $\begin{array}{l}6 \\
(3.9 \\
\%)\end{array}$ & - & $\begin{array}{l}4.2 \\
2\end{array}$ & $\begin{array}{l}73 \\
.2 \\
1\end{array}$ & A \\
\hline 4. & $\begin{array}{l}\text { Teachers support for one } \\
\text { another encourages } \\
\text { personal development }\end{array}$ & $\begin{array}{l}66 \\
(42 \\
.6\end{array}$ & $\begin{array}{l}71 \\
(45 \\
.8 \\
\%\end{array}$ & $\begin{array}{l}15 \\
(9.7 \\
\%)\end{array}$ & $\begin{array}{l}3 \\
(1.9 \\
\%)\end{array}$ & - & $\begin{array}{l}4.2 \\
3\end{array}$ & $\begin{array}{l}72 \\
.0 \\
5\end{array}$ & A \\
\hline 5. & $\begin{array}{l}\text { With the support of } \\
\text { experience teachers, new } \\
\text { teachers gain more } \\
\text { effectiveness and become } \\
\text { more efficient }\end{array}$ & $\begin{array}{l}85 \\
(54 \\
.8 \\
\%)\end{array}$ & $\begin{array}{l}63 \\
(40 \\
6 \\
\%)\end{array}$ & $\begin{array}{l}3 \\
(1.9 \\
\%)\end{array}$ & $\begin{array}{l}4 \\
2.6 \\
\%)\end{array}$ & - & $\begin{array}{l}4.4 \\
8\end{array}$ & $\begin{array}{l}66 \\
.7 \\
8\end{array}$ & $\mathrm{~A}$ \\
\hline 6. & $\begin{array}{l}\text { With the support of other } \\
\text { teachers there is increase in } \\
\text { output. }\end{array}$ & $\begin{array}{l}64 \\
(41 \\
3 \\
\%)\end{array}$ & $\begin{array}{l}68 \\
(43 \\
.9 \\
\%)\end{array}$ & $\begin{array}{l}15 \\
(9.7 \\
\%)\end{array}$ & $\begin{array}{l}8 \\
5.2 \\
\%)\end{array}$ & - & $\begin{array}{l}4.2 \\
1\end{array}$ & $\begin{array}{l}82 \\
.1 \\
7\end{array}$ & A \\
\hline 7. & $\begin{array}{l}\text { Teachers support for one } \\
\text { another increase student's } \\
\text { performance. }\end{array}$ & $\begin{array}{l}59 \\
(38 \\
.1\end{array}$ & $\begin{array}{l}67 \\
(43 \\
.2\end{array}$ & $\begin{array}{l}15 \\
9.7 \\
\%)\end{array}$ & $\begin{array}{l}12( \\
7.7 \\
\%\end{array}$ & $\begin{array}{l}2 \\
(1 . \\
3\end{array}$ & $\begin{array}{l}4.0 \\
9\end{array}$ & $\begin{array}{l}94 \\
.9 \\
2\end{array}$ & $\mathrm{~A}$ \\
\hline 8. & $\begin{array}{l}\text { Adequate discipline is } \\
\text { maintained where teachers } \\
\text { support each other }\end{array}$ & $\begin{array}{l}64( \\
41 . \\
3 \% \\
)\end{array}$ & $\begin{array}{l}69( \\
44 . \\
5 \% \\
)\end{array}$ & $\begin{array}{l}14 \\
(9.0 \\
\%)\end{array}$ & $\begin{array}{l}8 \\
(5.2 \\
\%\end{array}$ & - & $\begin{array}{l}4.2 \\
1\end{array}$ & $\begin{array}{l}81 \\
.6 \\
0\end{array}$ & $\mathrm{~A}$ \\
\hline
\end{tabular}

Table 3shows the responses of respondents on the impact of motivation on teacher collaboration and on the job effectiveness. Their responses to the items indicate that their mean score in all the items are 4 point and above showing significant contribution of motivation on teachers' collaboration and on the job effectiveness. The study shows that $54.8 \%$ totaling 85 respondents, and $60 \%$ representing 93 respondents agree when teachers are adequately motivated, it enhances cooperation them and in turn facilitates on the job effectiveness among them.

\section{Discussion:}

The response of the respondents to research question one indicates that majority are in agreement that collaboration and on the job effectiveness could be achieved through constant interaction, team work, group discussion, cheering each other up, and exchange of ideas and this in turn enhances high degree of professional input and individual development. McLaughlin and Talbert (2001) found teachers conversation and collaboration to be important component of professional development. Horn (2006) also sees teachers' conversation as a correlate to the translation of 
abstract pedagogical ideas into complex realities as well as a factor that sustains professional engagement in such a way that high quality professional development is maximized. Responses to research question two also indicate that the respondents agree that cooperation, good working relationship, closeness, and cordiality among teachers could enhance on the job effectiveness. This agrees with the assertion of Anderson and Ward (2005) that collaborative relationship provides more direct instructional activities and differentiated content planning, preparation, reduced student teacher ratio, professional learning opportunities, and less disciplinary cases for referrals. This shows that when there is strong relational process among teachers, individuals can benefit from such relationship and as well improve in their professional practice. The result in table 3 showsclear evidence that when teachers' are motivated, their level of efficiency on the job improves. The actions of others act as stimulus that stimulates others to effective performance. The study also revealed that the motivation of teachers affects high productivity and also exerts high influence on the academic outcome of students. Hence, schools that expect productivity and good students' performance should take cognizance of the outcome of this study, in the area of teacher's motivation. Audu and Oliha (2008) asserted that teacher morale can serve as an essential factor in the successful implementation of educational programs. To them, teachers' motivation affects students' academic outcome.

\section{Conclusion:}

Teachers' interaction process serves as a positive correlate to professional effectiveness. Hence their constant interaction, cooperation, and closeness remain vital relational correlate to maximizing effectiveness in the profession. Motivation remains a vital tool for teacher effectiveness which in turn affects students' academic outcome. Teacher can derive motivation from each other if the relational variables are held constant. The insignificant level of variance from the respondents' responses may be attributed to other environmental variables. One fact remains that teacher collaboration as well remain a strong factor for achieving professional effectiveness.

\section{Recommendations:}

1. The study has revealed so much on the impact of relational correlates on teacher collaboration and teacher effectiveness therefore it is recommended that teachers should initiate at all levels the process of coming together to plan, organize, and share experiences.

2. Teachers should also devise means of motivating themselves even when none is coming from external sources by encouraging each other in times of challenges, joining their experiences together in finding solution to professional challenges, helping each other to improve on the practice.

3. Relationship has proved to be a strong and vital ingredient for facilitating teachers' collaboration and effectiveness on the job and profession. Hence there is need for teacher to develop strong relational framework in other to benefit from one another.

4. Generally, employers should take advantage of the outcome of this study in other to help them achieve their objective and maximize the potentials of the teachers fully. 
International Journal of Education (IJE), Vol. 3, No. 3, September 2015

\section{REFERENCES:}

[1] Audu, Y. L. \& Oliha, J. A. (2008). Counseling for transparent leadership: The impact of Principal's leadership style on Teachers morale and students academic achievement. African Journal of studies in Education, 4 (1), 148-164.

[2] Armstrong, K. (2009). The path to better health and wellbeing in education.

[3] Anderson, T. C. \& Ward, N. M> (2005). A co teaching handbook for workshop participants. In B. A. Smith, (2007). Increasing the comfort level of teachers toward inclusion through use of school focus groups.

[4] Bartell, C.A. (1990). Outstanding secondary school Principals reflect on International Leadership. The high school Journal 72, 118-128. In V. L.

[5] Audu, and J.A. Oliha (2008). Counseling for transparent leadership: The Principal's style on teachers moral and students' academic achievement.

African Journal of studies in Education.

[6] Gable, R.A. \& Manning L. (2009). The role of teacher collaboration in school reform. America: Questa Media. Retrieved from http://www.questa.com.

[7] Gbenga, O. (2010). Increasing the viability of Nigerian economy through effective teacher education. African Journal of historical sciences in education, 6(1), 192-207.

[8] Kings, S. (2000). Principals influence culture of inclusion. High school imagazine, 7(7) 45-46.

[9] Little J. W. (1990). Teachers as colleagues. In A. Liberman (Ed). Schools as collaborative cultures: Creating future now, pp.165-193. Bristle: The farmer Press

[10] Moore, w. (2005). Teachers stress pressures of life of the chalkface. Retrieved from http://www.teacherstress.co.uk/index.shtml.

[11] New Teacher Center (2007). New Teachers support pays off: A return on investment for educators and kids. University of California.

[12] Nwachukwu, C. I. (2011). Overview of the effects of motivation on academic achievement of students. A paper presented at the national conference of Nigerian Society of Educational Psychologist, Makurdi 2011.

[13] Okoro, F. I. (2008). Strategies for enhancing teacher effectiveness in the university system. African Journal of studies in Education, 4 (1), 173-189.

[14] Onete, O. U. Udey, F. U. \& Ogbor, B. P. (2011). Academic performance: A function of achievement motivation among education students of CrossRiver

[15] university of Technology. A presented at the National conference of Nigerian Society for Educational Psychologists in Makudi 2011.

[16] Raganee, N. (2008). Teacher collaboration strategies to overcome barriers to effective collaboration in the foundation phase. Retrieved from http://www.hdl.hnadle.net/10210/1289.

[17] Teacher support Network (2005). Teacher wellbeing positive steps to improve school performance. Retrieved from http://www.worklifesupport.com.

[18] Van Driel, J. H. Beijaard, D, \& Verloop, N. (2001). Professional development and reform in science education: The role of teachers practical knowledge. Journal of Research in Science Teaching, 38, 137158.

[19] Wallace, C. S. (2006). Teacher collaboration for science activity design. The free library. Retrieved from http://www.thefreelibrary.com. Academic Exchange Quarterly.

[20] Wilson \& Berne, J. (1999). Teacher learning and the acquisition of professional knowledge: An examination of research on contemporary professional development. Review of research in Education, 24. 173-209. Retrieve from hpp://www.newhorizons.org. 